"Mircea cel Batran" Naval Academy Scientific Bulletin, Volume XIX - 2016 - Issue 1

Published by "Mircea cel Batran" Naval Academy Press, Constanta, Romania // The journal is indexed in:

PROQUEST / DOAJ / DRJI / JOURNAL INDEX / I2OR / SCIENCE LIBRARY INDEX / Google Scholar / Crossref /

Academic Keys / ROAD Open Access / OAJI / Academic Resources / Scientific Indexing Services / SCIPIO

\title{
VIBRATION ANALYSIS FOR DETECTION AND LOCALIZATION THE FAULTS OF ROTATING MACHINERY USING WAVELET TECHINIQUES
}

\author{
Mihail PRICOP ${ }^{1}$ \\ Codruta PRICOP2 \\ Ionuț-Cristian SCURTU ${ }^{3}$ \\ Tiberiu PAZARA ${ }^{4}$ \\ Alecu TOMA ${ }^{5}$ \\ ${ }^{1}$ Associate professor, Eng., PhD, "Mircea cel Batran" Naval Academy, Constanta, Romania \\ ${ }^{2}$ Associate Professor, Eng., PhD, Maritime University, Constanța, Romania, pricopcodruta@yahoo.com \\ ${ }^{3}$ LTJG (N) instr.Eng. , PhD, "Mircea cel Batran" Naval Academy, Constanta, Romania, ionut.scurtu@anmb.ro \\ ${ }^{4}$ Lecturer, PhD, "Mircea cel Batran" Naval Academy, Constanta, Romania, tiberiu.pazara@anmb.ro \\ 5Lecturer, PhD, "Mircea cel Batran” Naval Academy, Constanta, Romania, alecu.toma@anmb.ro
}

\begin{abstract}
Vulnerable and critical mechanical systems are bearings and drive belts. Signal analysis of vibration highlights the changes in root mean square, the frequency spectrum (frequencies and amplitudes) in the time-frequency (Short Time Fourier Transform and Wavelet Transform), are the most used method for faults diagnosis and location of rotating machinery.

This article presents the results of an experimental study applied on a diagnostic platform of rotating machinery through three Wavelet methods: (Discrete Wavelet Transform -DWT, Continuous Wavelet Transform -CWT, Wavelet Packet Transform-WPT) with different mother wavelet.

Wavelet Transform is used to decompose the original signal into sub-frequency band signals in order to obtain multiple data series at different resolutions and to identify faults appearing in the complex rotation systems. This paper investigates the use of different mother wavelet functions for drive belts and bearing fault diagnosis. The results demonstrate the possibility of using different mother wavelets in rotary systems diagnosis detecting and locating in this way the faults in bearings and drive belts.
\end{abstract}

Keywords: bearings, drive belts, Discrete Wavelet Transform, Continuous Wavelet Transform, Wavelet Packet Transform, mother wavelets

\section{INTRODUCTION}

Belts and bearings are components of a power transmission system (fig.1) requiring a permanent and careful monitoring. Recent research has focused on the study and diagnosis of faults in elements transmission gears and bearings gear being used a number of techniques classics like FFT, Wigner-Ville distribution [1], wavelet analysis [2] of the static signal or intelligent as ANN-based method, the Guarantee based expert system.

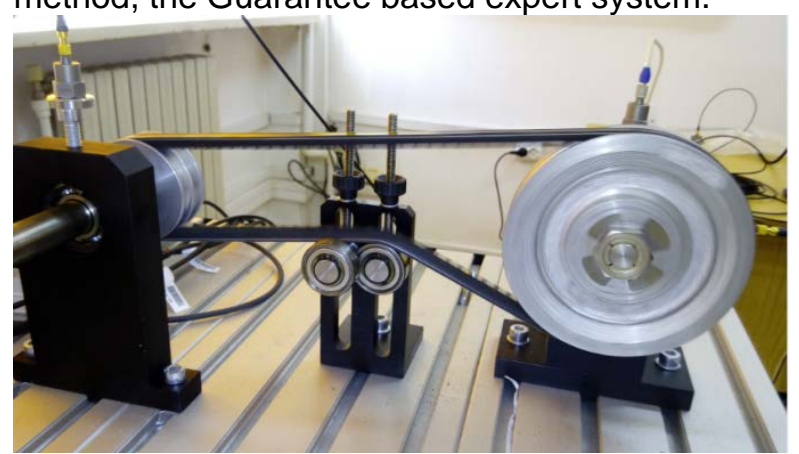

Fig.1. Mechanical belt transmission analyzed

Wavelet transform [2] is most commonly used as a method for signal processing stationary and non-stationary time-frequency domain simultaneously. The question is which methods wavelet transform (DWT, CWT or WPT) are more effective taking into account on the one hand to form discrete or continuous analyzed signal derived from the system belt-bearing and secondly the characteristics of mother wavelet used function to diagnose faults.

The signal is processed by wavelet transform raw signal can be direct or some form of it as a residual signal [3], time synchronous averaged (TSA), de-noising signal.

The power transmission system components are defects harmonic form and / or pulse. Levels of decomposition is selected depending on the necessity to determine the characteristics of the signal changes at every level for the four conditions of the experiment (normal system, defect-bearing outer ring belt defect, defectbearing inner ring belt defect, defect ball rolling bearing- fault belt). In this regard should be taken of the energy distribution of signals in the timefrequency vibration or location - scale for different degrees of advancement defects.

\section{THEORETICAL BACKGROUNDS}

The main advantage of using wavelet transform is that it makes an analysis of the local signal or may analyze a portion or extract signal level without losing spectral information. Thus, wavelet 
"Mircea cel Batran" Naval Academy Scientific Bulletin, Volume XIX - 2016 - Issue 1

Published by "Mircea cel Batran" Naval Academy Press, Constanta, Romania /I The journal is indexed in:

PROQUEST / DOAJ / DRJI / JOURNAL INDEX / I2OR / SCIENCE LIBRARY INDEX / Google Scholar / Crossref /

Academic Keys / ROAD Open Access / OAJI / Academic Resources / Scientific Indexing Services / SCIPIO

transforms are able to identify some important features of signal that other methods are unable to detect. The Continuous Wavelet Transform (CWT) of the signal $\mathrm{s}(\mathrm{t})$ is defined as follows:

$W_{s}(b, a)=a^{-1 / 2} \int_{-\infty}^{+\infty} s\left(t^{\prime}\right) \psi\left[\frac{\left(t^{\prime}-b\right)}{a}\right] d t^{\prime}$

where $\Psi(t)$ is the basic wavelet or mother wavelet, $a$ is the scale parameter and $b$ represents the position parameter. The wavelet transform, defined as an inner product between $s(t)$ and $\psi\left(\frac{t-b}{a}\right)$, scaled and shifted versions of basic wavelet $\psi(t)$, reflects similarity of the signal $s(t)$ with wavelet $\psi(t)$.

Small scales correspond to high frequency (coarse frequency resolution and fine time resolution). Large scales correspond to low frequency (fine frequency resolution and coarse time resolution). The position parameter, b, gives the localization in time at scale a.

The goal of the signal analysis with continuous wavelet transform is to calculate local scaling exponents at various points in the signal.

The wavelet signal analysis based by Discrete Wavelet Transform (DWT) is a time/frequency method that decompose signal in low frequency and high-frequency components.

Signal decomposition through Discrete Wavelet Transform can be efficiently realized by means of a pair of low - pass and high - pass wavelet filter, denoted as $\mathrm{h}(\mathrm{k})$ and $g(k)=(-1)^{k} h(1-k)$, respectively.

These filters, also known as Quadrature Mirror Filters (QMF), are constructed from the selected mother wavelet $\psi(t)$ and its corresponding scaling function $\phi(t)$, expressed as:

$$
\left\{\begin{array}{l}
\phi(t)=\sqrt{2} \sum_{k} h(k) \phi(2 t-k) \\
\psi(t)=\sqrt{2} \sum_{k} g(k) \psi(2 t-k)
\end{array}\right.
$$

Using the wavelet filters, the analyzed signal is decomposed into a set of low and high frequency components:

$$
\left\{\begin{array}{l}
\mathrm{a}_{\mathrm{j}, \mathrm{k}}=\sum_{\mathrm{m}} \mathrm{h}(2 \mathrm{k}-\mathrm{m}) \mathrm{a}_{\mathrm{m}, \mathrm{j}-1} \\
\mathrm{~d}_{\mathrm{j}, \mathrm{k}}=\sum_{\mathrm{m}} \mathrm{g}(2 \mathrm{k}-\mathrm{m}) \mathrm{a}_{\mathrm{m}, \mathrm{j}-1}
\end{array}\right.
$$

In this equation, $a_{j, k}$ is the approximation coefficient, which represents the low - frequency component of the signal, and $d_{j, k}$ is the detail coefficient, which corresponds to the high - frequency component. The approximate and detail coefficients at wavelet scale $2^{j}$ (with j denoting the level) are obtained by convolving the approximate coefficients at the previous level $(j-1)$ with the low - pass and high - pass filter coefficients, respectively.

Packets Wavelet Transform (WPT) are linear combinations of functions and wavelet decomposition signal analyzed in detail components at different scales respective approximate. In these way monitoring faults via WPT packages which have sought defect frequencies equal frequency, using a small number of signal samples. Similarly, as in other wavelet transformed, WPT effectiveness of the method is determined by the mother wavelet function selection

WPT analysis based on DWT is a generalization of wavelet decomposition and provides a richer range of signal analysis options. Method WPT decomposes also each detail component in order to achieve more accurate information. A wavelet packet is a function defines as follows:

$\psi_{j, k}^{i}(t)=2^{j / 2} \psi^{j}\left(2^{j} t-k\right), i=1,2,3 \ldots$

where i, j, $\mathrm{k}$ are the modulation, scale and translation parameters.

Functions $\psi^{j}$ are calculated from recursive equations:

$$
\begin{gathered}
\psi^{2 j}(t)=\sqrt{2} \sum_{-\infty}^{\infty} h(k) \psi^{j}(2 t-k) \\
\psi^{2 j+1}(t)=\sqrt{2} \sum_{-\infty}^{\infty} g(k) \psi^{j}(2 t-k)
\end{gathered}
$$

Analyzed signal $s(t)$ at $j$ modulation level is defined:

$$
f(t)=\sum_{i=1}^{2 j} f_{j}^{i}(t)
$$

Signal component from wavelet is determined:

$$
f_{j}^{i}(t)=\sum_{k=-\infty}^{\infty} c_{j k}^{i}(t) \psi_{j, k}^{i}(t)
$$

Wavelet packet coefficients are obtained from:

$$
c_{j k}^{i}(t)=\int_{-\infty}^{m} f(t) \psi_{j k k}^{i}(t) d t .
$$

Wavelet packet functions must satisfy the orthogonality condition.

$$
\psi_{j, k(t)}^{m} \psi_{j k}^{n}(t)=0 \text { if } m \neq n .
$$


"Mircea cel Batran" Naval Academy Scientific Bulletin, Volume XIX - 2016 - Issue 1

Published by "Mircea cel Batran" Naval Academy Press, Constanta, Romania // The journal is indexed in: PROQUEST / DOAJ / DRJI / JOURNAL INDEX / I2OR / SCIENCE LIBRARY INDEX / Google Scholar / Crossref / Academic Keys / ROAD Open Access / OAJI / Academic Resources / Scientific Indexing Services / SCIPIO

\section{EXPERIMENTAL ANALYSIS AND}

\section{RESULTS}

For the experiment we used a stand for defects in a rotating system, compose of an electric motor which by means of an elastic shaft coupling transmits a rotational movement to a belt under load. The shaft is supported by two bearings at the ends bearing 6004 . The bearing type has the following characteristics: Bearing 6004 diameter: $20 \mathrm{~mm}$; external diameter: $42 \mathrm{~mm}$; Thickness: $12 \mathrm{~mm}$. The trapezoidal belt is a XPZ series belt.

Table 1 Frequency components of the rotation system

\begin{tabular}{|l|l|l|l|}
\hline \multirow{2}{*}{$\begin{array}{l}\text { Compone } \\
\text { nt }\end{array}$} & \multicolumn{4}{|l|}{ Engine speed } \\
\cline { 2 - 4 } & $\begin{array}{l}\mathrm{n}_{1}=500 \mathrm{r} \\
\mathrm{pm}\end{array}$ & $\begin{array}{l}\mathrm{N}_{2}=1500 \mathrm{r} \\
\mathrm{pm}\end{array}$ & $\begin{array}{l}\mathrm{N}_{3}=2500 \mathrm{r} \\
\mathrm{pm}\end{array}$ \\
\hline Shaft & $8.3 \mathrm{~Hz}$ & $24.9 \mathrm{~Hz}$ & $41.5 \mathrm{~Hz}$ \\
\hline $\begin{array}{l}\text { Bearing } \\
\text { outer ring }\end{array}$ & $29.8 \mathrm{~Hz}$ & $89.5 \mathrm{~Hz}$ & $149.1 \mathrm{~Hz}$ \\
\hline $\begin{array}{l}\text { Bearing } \\
\text { inner ring }\end{array}$ & $45.2 \mathrm{~Hz}$ & $135.5 \mathrm{~Hz}$ & $225.9 \mathrm{~Hz}$ \\
\hline $\begin{array}{l}\text { Bearing } \\
\text { ball }\end{array}$ & $39 \mathrm{~Hz}$ & $116.9 \mathrm{~Hz}$ & $194.9 \mathrm{~Hz}$ \\
\hline $\begin{array}{l}\text { Transmiss } \\
\text { ion belt }\end{array}$ & $1.8 \mathrm{~Hz}$ & $5.4 \mathrm{~Hz}$ & $9 \mathrm{~Hz}$ \\
\hline
\end{tabular}

Vibration signals were recorded through three channels located on two bearings with bearings for rotating three regimes (Table 1) and four situations defective ball, outer race, and inner race belt defect (Table 2 ).



Fig.2. Belt arrangement and sensors

Tabel.2. Situations faulty system components

\begin{tabular}{|l|c|l|l|l|l|}
\hline $\begin{array}{l}\text { Runni } \\
\text { ng } \\
\text { spee } \\
\text { d } \\
\text { [rpm] }\end{array}$ & $\begin{array}{c}\text { Normal } \\
\text { bearing }\end{array}$ & $\begin{array}{l}\text { Outer } \\
\text { race } \\
\text { fefect } \\
\text { faulty } \\
\text { Felty } \\
\text { belt }\end{array}$ & $\begin{array}{l}\text { Inner } \\
\text { race } \\
\text { defect } \\
\text { Faulty } \\
\text { belt }\end{array}$ & $\begin{array}{l}\text { Ball } \\
\text { defect } \\
\text { Faulty } \\
\text { belt }\end{array}$ & $\begin{array}{l}\text { Normal } \\
\text { bearing } \\
\text { Good } \\
\text { conditio } \\
\text { n belt }\end{array}$ \\
\hline 500 & $\begin{array}{c}\text { Record } \\
80\end{array}$ & $\begin{array}{c}\text { Record } \\
83\end{array}$ & $\begin{array}{c}\text { Record } \\
86\end{array}$ & $\begin{array}{c}\text { Recor } \\
\text { d } 89\end{array}$ & $\begin{array}{c}\text { Record } \\
94\end{array}$ \\
\hline 1500 & $\begin{array}{c}\text { Record } \\
81\end{array}$ & $\begin{array}{c}\text { Record } \\
84\end{array}$ & $\begin{array}{c}\text { Record } \\
87\end{array}$ & $\begin{array}{c}\text { Recor } \\
\text { d } 90\end{array}$ & $\begin{array}{c}\text { Record } \\
95\end{array}$ \\
\hline
\end{tabular}

\begin{tabular}{|c|c|c|c|c|c|}
\hline 2500 & $\begin{array}{c}\text { Record } \\
82\end{array}$ & $\begin{array}{c}\text { Record } \\
85\end{array}$ & $\begin{array}{c}\text { Record } \\
88\end{array}$ & $\begin{array}{c}\text { Recor } \\
\text { d 91 }\end{array}$ & $\begin{array}{c}\text { Record } \\
96\end{array}$ \\
\hline
\end{tabular}

The recorded signals were decomposed with MATLAB - Wavelet toolbox through Discrete Daubechies 4 Wavelet Transform at 5 level decomposition.

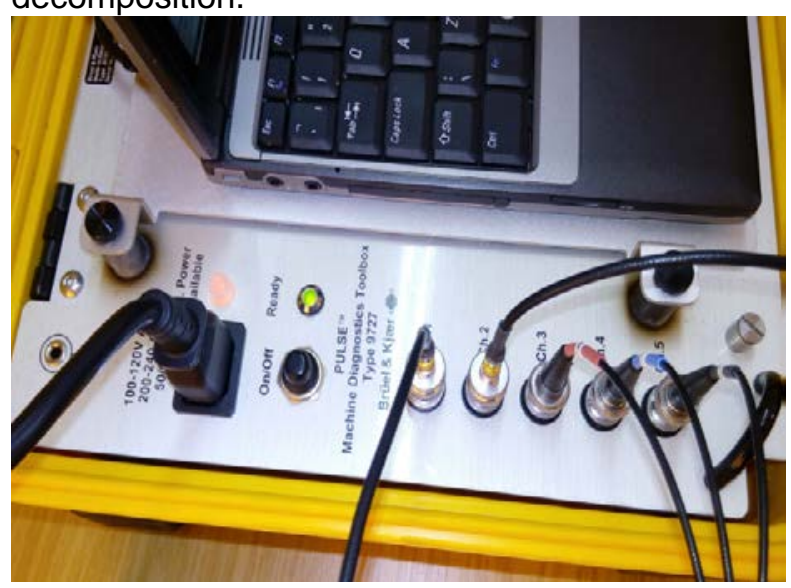

Fig.3 Pulse hardware tools

The Discrete Wavelet transform split the frequency band of the signal into disjunct frequency bands as related in Table 3 .

Table.3. Discrete Wavelet Transform (DWT) and splitting of the frequency band for the recorded signal

\begin{tabular}{|c|c|c|}
\hline Signal & Band: $[0 ; 1.6 \mathrm{kHz}$ & \\
\hline $\begin{array}{l}1^{\text {st }} \text { level Discrete } \\
\text { Wavelet } \\
\text { Decomposition }\end{array}$ & $\begin{array}{c}\text { Approximation } \\
\text { a1: } \\
{[0 ; 0.8 \mathrm{kHz}]}\end{array}$ & $\begin{array}{c}\text { Details d1: } \\
{[0.8 ; 1.6 \mathrm{kHz}]}\end{array}$ \\
\hline $\begin{array}{l}2^{\text {nd }} \text { level Discrete } \\
\text { Wavelet } \\
\text { Decomposition }\end{array}$ & $\begin{array}{c}\text { Approximation } \\
\text { a2: } \\
{[0 ; .400 \mathrm{~Hz}]}\end{array}$ & $\begin{array}{c}\text { Details d2: } \\
\text { [400;.800 Hz] }\end{array}$ \\
\hline $\begin{array}{l}3^{\text {rd }} \text { level Discrete } \\
\text { Wavelet } \\
\text { Decomposition }\end{array}$ & $\begin{array}{c}\text { Approximation } \\
\text { a3: } \\
{[0 ; 200 \mathrm{~Hz}]}\end{array}$ & $\begin{array}{l}\text { Details d3: } \\
\text { [200; } 400 \mathrm{~Hz}]\end{array}$ \\
\hline $\begin{array}{l}4^{\text {th }} \text { level Discrete } \\
\text { Wavelet } \\
\text { Decomposition }\end{array}$ & $\begin{array}{c}\text { Approximation } \\
\text { a4: } \\
{[0 ; 100 \mathrm{~Hz}]}\end{array}$ & $\begin{array}{c}\text { Details d4: } \\
\text { [100Hz; } 200 \mathrm{~Hz}]\end{array}$ \\
\hline $\begin{array}{l}5^{\text {th }} \text { level Discrete } \\
\text { Wavelet } \\
\text { Decomposition }\end{array}$ & $\begin{array}{c}\text { Approximation } \\
\text { a5: } \\
{[0 ; 50 \mathrm{~Hz}]}\end{array}$ & $\begin{array}{l}\text { Details d5: } \\
{[50 ; 100 \mathrm{~Hz}]}\end{array}$ \\
\hline
\end{tabular}

In fig. 4-9 are shown recorded signals DWT decomposition for the 4 cases of faults. Each signal has 2048 samples. Were used five levels of decomposition using $\mathrm{Db} 4$ mother wavelet function $[4,5]$. Also for two different situations, one defective inner ring-fault belt and the second no defects, are presented details coefficients on the levels of decomposition in scale of colors. Coefficients of wavelet are clearly distinguished irregularities introduced by the bearing defect at $89.5 \mathrm{~Hz}$ frequency identified in detail 4 and the 
"Mircea cel Batran" Naval Academy Scientific Bulletin, Volume XIX - 2016 - Issue 1

Published by "Mircea cel Batran" Naval Academy Press, Constanta, Romania // The journal is indexed in: PROQUEST / DOAJ / DRJI / JOURNAL INDEX / I2OR / SCIENCE LIBRARY INDEX / Google Scholar / Crossref I

Academic Keys / ROAD Open Access / OAJI / Academic Resources / Scientific Indexing Services / SCIPIO

drive belt defect identified in detail 5 , at $5.4 \mathrm{~Hz}$ frequency.



Fig.4 DWT_db4 signal 2 with 2048 samples with defective belt and the faulty outer ring at the speed $1500 \mathrm{rpm}$


Fig.5 DWT_db4 signal 2 with 2048 samples with defective belt and the faulty outer ring at the speed 1500 rpm-Superimpose Mode



(C) 2015. This work is licensed under the Creative Commons Attribution-Noncommercial-Share Alike 4.0 License.
Fig.6 DWT_db4 signal 2 with 2048 samples with defective belt and the faulty inner ring at the speed $1500 \mathrm{rpm}$

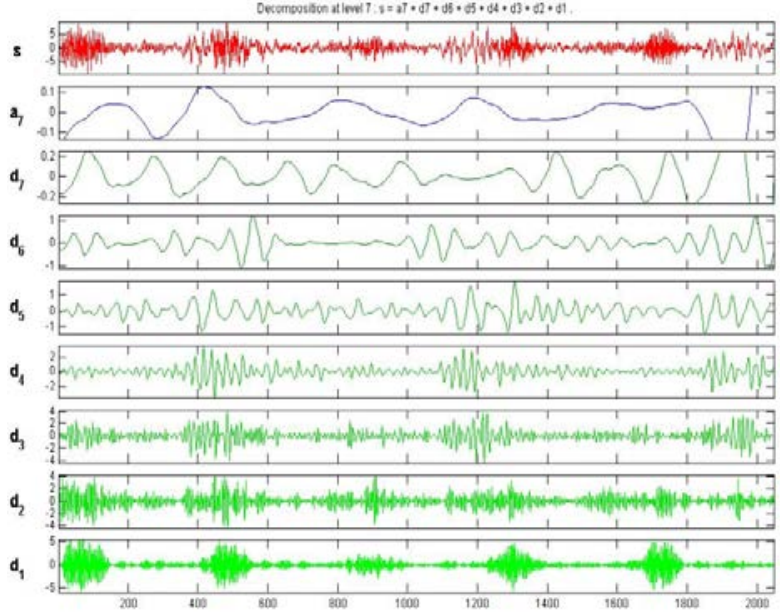

Fig.7 DWT_db4 signal 2 with 2048 samples with defective belt and the faulty bearing ball at the speed $1500 \mathrm{rpm}$



Fig.8 DWT_db4 signal 2 with 2048 samples without faulty components at $1500 \mathrm{rpm}$
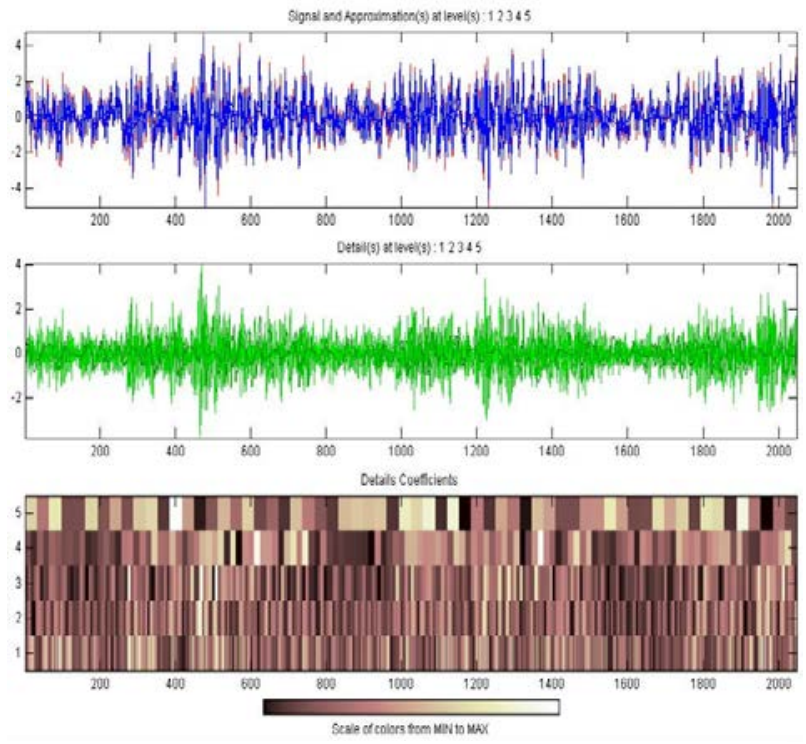

Fig.9 DWT db4 signal 2 with 2048 samples without faulty components at $1500 \mathrm{rpm}$ Superimpose Mode 
"Mircea cel Batran" Naval Academy Scientific Bulletin, Volume XIX - 2016 - Issue 1

Published by "Mircea cel Batran" Naval Academy Press, Constanta, Romania // The journal is indexed in: PROQUEST / DOAJ / DRJI / JOURNAL INDEX / I2OR / SCIENCE LIBRARY INDEX / Google Scholar / Crossref / Academic Keys / ROAD Open Access / OAJI / Academic Resources / Scientific Indexing Services / SCIPIO

Are shown in figures 10-16 CWT of the recorded signals in the $1500 \mathrm{rpm}$ shaft rotation mode, using three types of mother wavelet function: Morlet, Daubechies and Haar. Signal frequency sampling is $4096 \mathrm{~Hz}$. Using comparative scale several areas sudden changes can be seen as a signal occurring at scales smaller values. Charts can be distinguished clearly from the belt and bearing defects. Morlet wavelet is used most often in decomposition techniques for diagnosing faults vibration signals engaging elements. Morlet wavelet [5] mother has the best similarity for both types of signals and simultaneously identify defects in the drive belt and ball.

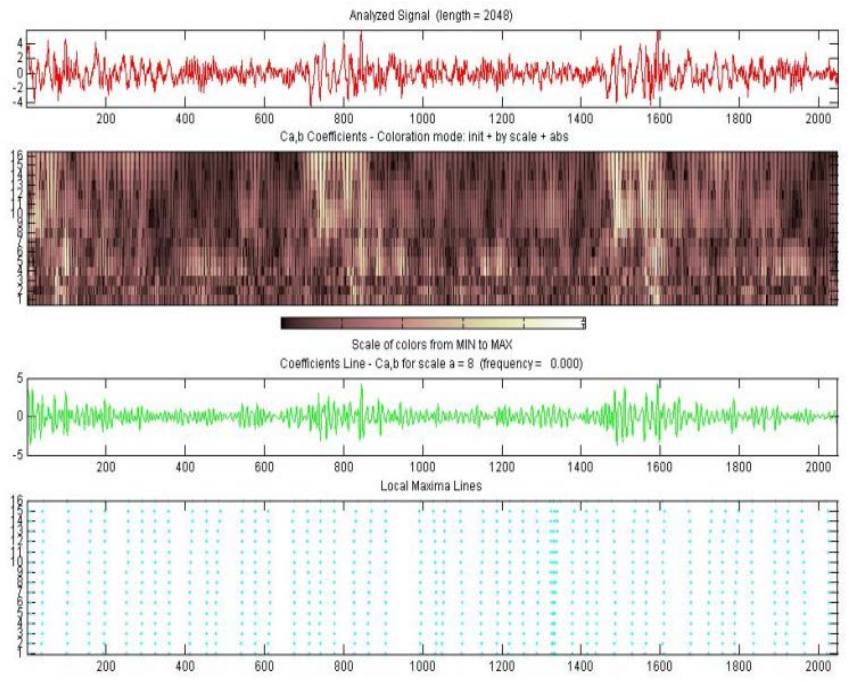

Fig.10 CWT_morl signal 2 with 2048 samples with defective belt and the faulty outer ring at the speed $1500 \mathrm{rpm}$
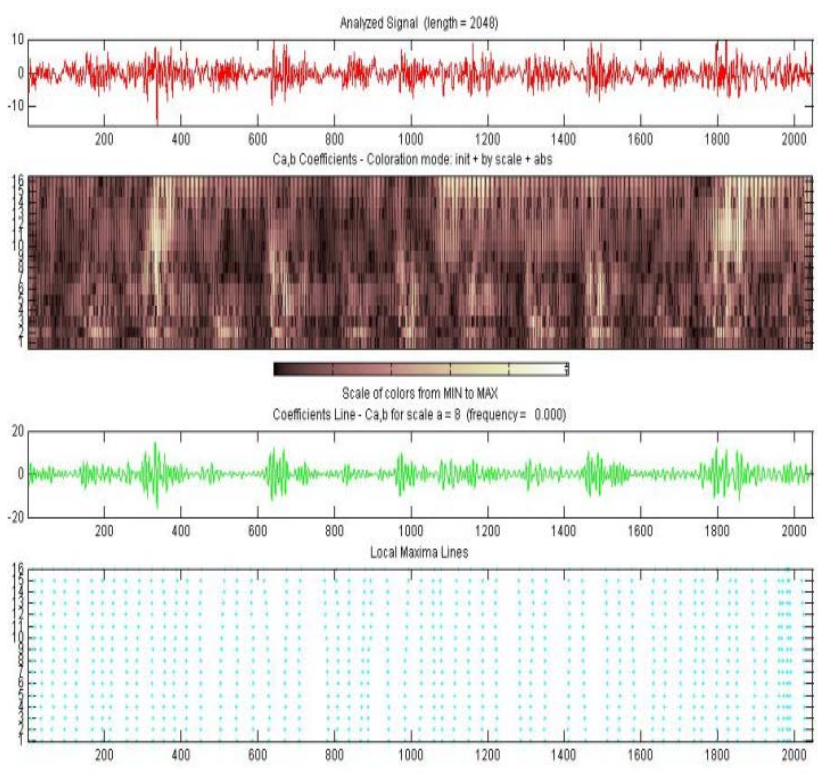

Fig.11 CWT_morl signal 2 with 2048 samples with defective belt and the faulty inner ring at the speed $1500 \mathrm{rpm}$
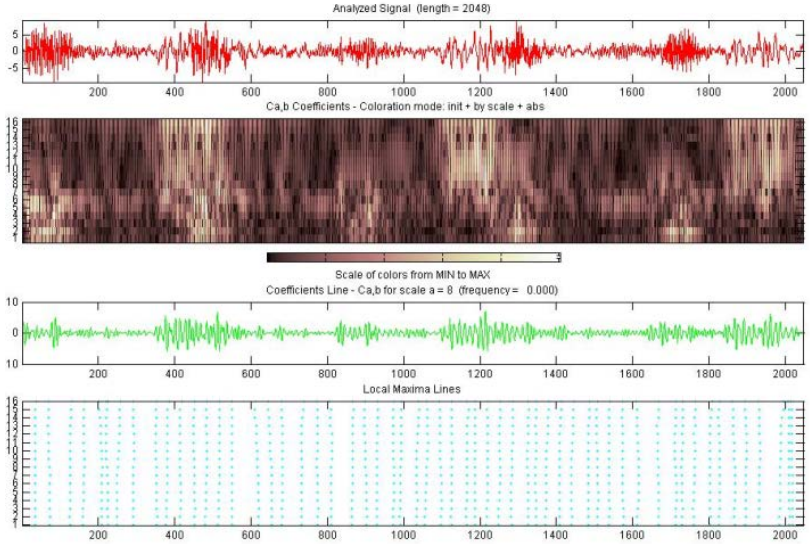

Fig.12 CWT_morl signal 2 with 2048 samples with defective belt and the faulty bearing ball at the speed $1500 \mathrm{rpm}$

Drive belt defects are highlighted with mother Haar wavelet function by locating the temporal discontinuities or singularities of the signal using maximum modulus lines (fig.13)

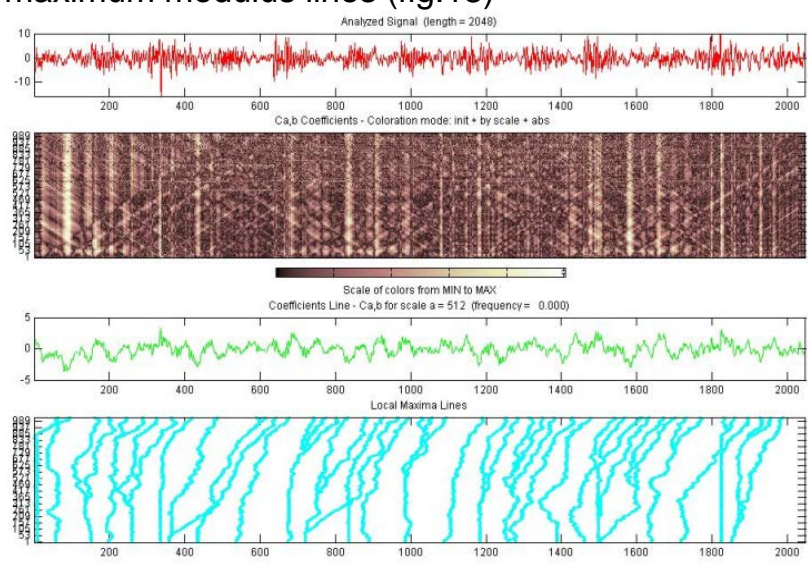

Fig.13. CWT_haar signal 2 with 2048 samples with defective belt and the faulty outer ring at the speed $1500 \mathrm{rpm}$

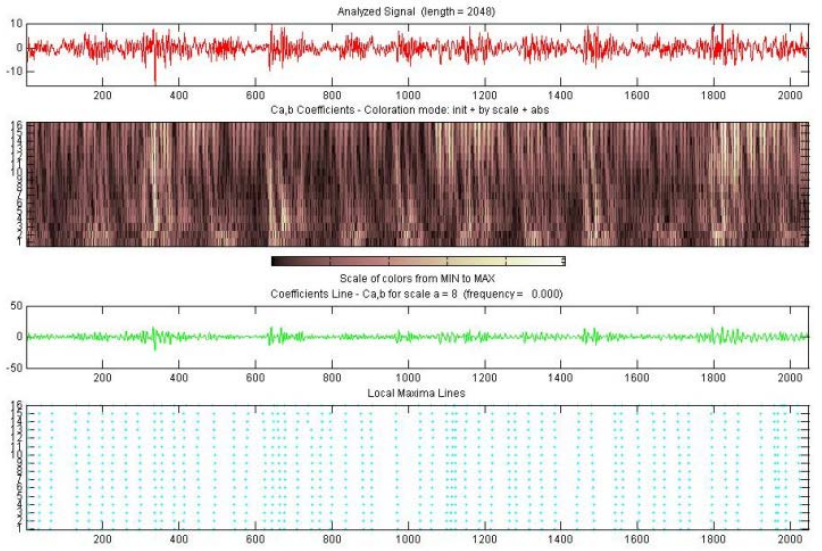


"Mircea cel Batran" Naval Academy Scientific Bulletin, Volume XIX - 2016 - Issue 1

Published by "Mircea cel Batran" Naval Academy Press, Constanta, Romania // The journal is indexed in: PROQUEST / DOAJ / DRJI / JOURNAL INDEX / I2OR / SCIENCE LIBRARY INDEX / Google Scholar / Crossref / Academic Keys / ROAD Open Access / OAJI / Academic Resources / Scientific Indexing Services / SCIPIO

Fig.14 CWT_db4 signal 2 with 2048 samples with defective belt and the faulty inner ring at the speed $1500 \mathrm{rpm}$
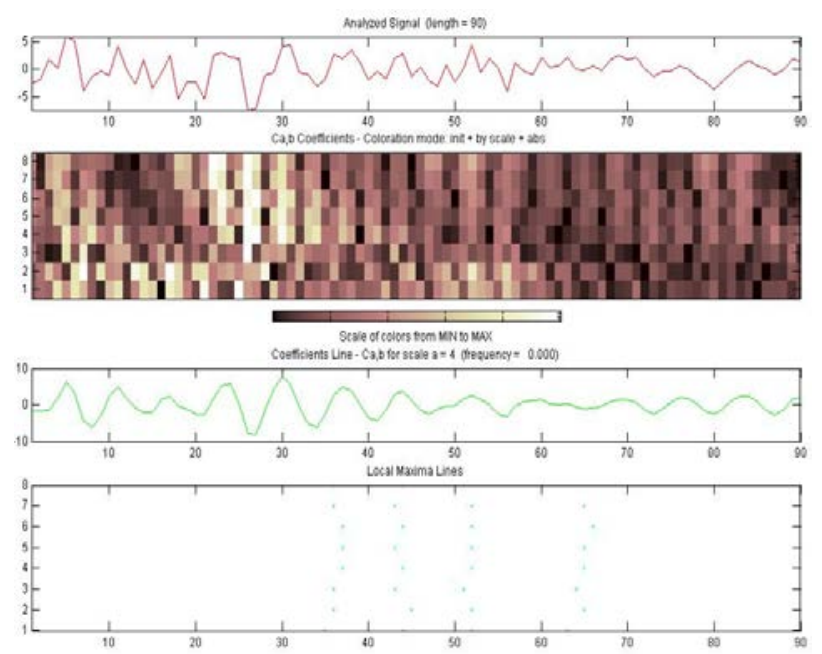

Fig.15 CWT_db4 signal 2 with 90 samples scale $a=4$, with defective belt and the faulty inner ring at the speed $1500 \mathrm{rpm}$
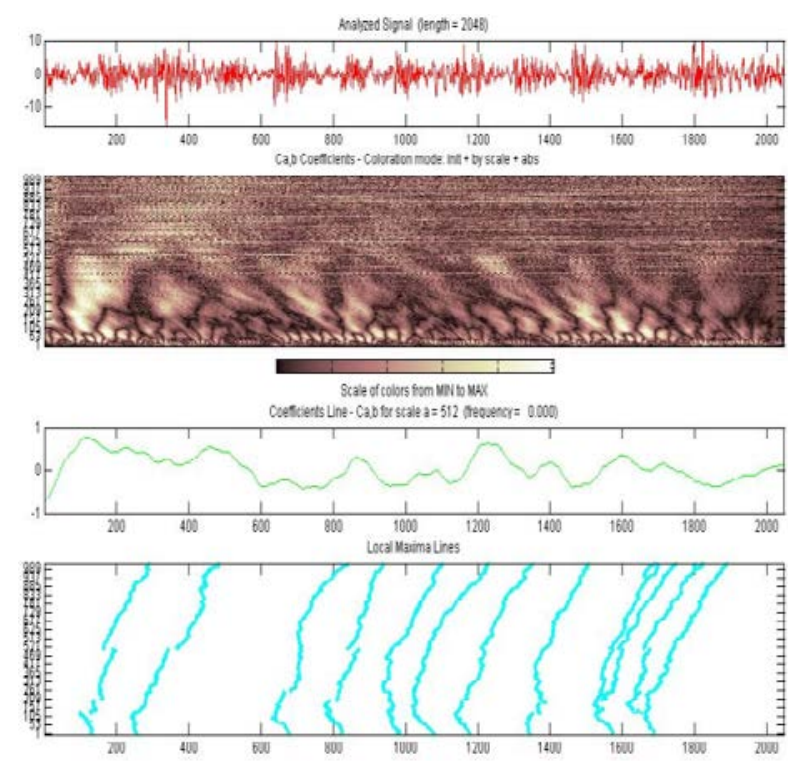

Fig.16 CWT_db4 signal 2 with 90 samples scale $a=512$, with defective belt and the faulty inner ring at the speed $1500 \mathrm{rpm}$

Wavelet Packet Transform is used for vibration signal decomposition and obtain the energy ratio in each frequency band. In this paper was used the mother wavelet function Db4, decomposing signal in 3 levels. By breaking signal was obtained binary tree structure of energy, using energy of wavelet function toolbox of Matlab and distribution coefficients on the 8 frequency bands where the 3rd level of decomposition.

In the charts, present in fig 17-18 the speed of $1500 \mathrm{rpm}$ and is clearly seen in the table summarizing the differences in energy reports to

(c) 2015. This work is licensed under the Creative Commons Attribution-Noncommercial-Share Alike 4.0 License. flaws in appearance and bearing belt in one frequency band between $0-200 \mathrm{~Hz}$, an area where there is the frequent faults.

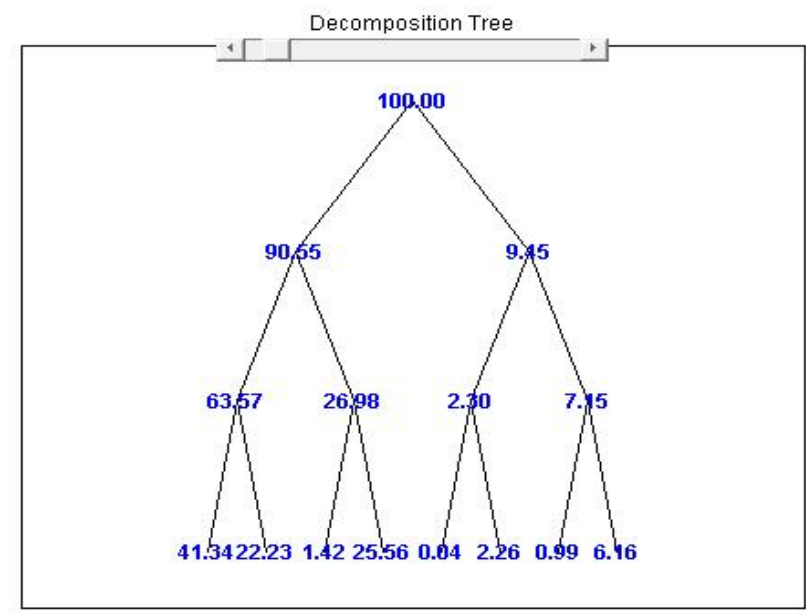

Fig.17. TRACK81_2_signal_2_2048_energy

Colored Coefficients for Terminal Nodes

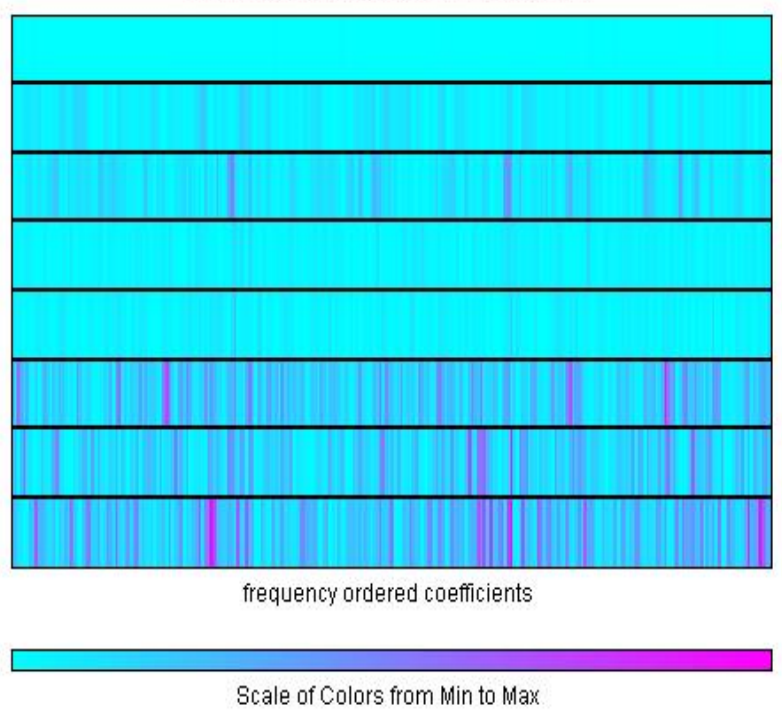

Fig.18 TRACK81_2_signal_2_2048_energy 
"Mircea cel Batran" Naval Academy Scientific Bulletin, Volume XIX - 2016 - Issue 1 Published by "Mircea cel Batran" Naval Academy Press, Constanta, Romania // The journal is indexed in: PROQUEST / DOAJ / DRJI / JOURNAL INDEX / I2OR / SCIENCE LIBRARY INDEX / Google Scholar / Crossref / Academic Keys / ROAD Open Access / OAJI / Academic Resources / Scientific Indexing Services / SCIPIO

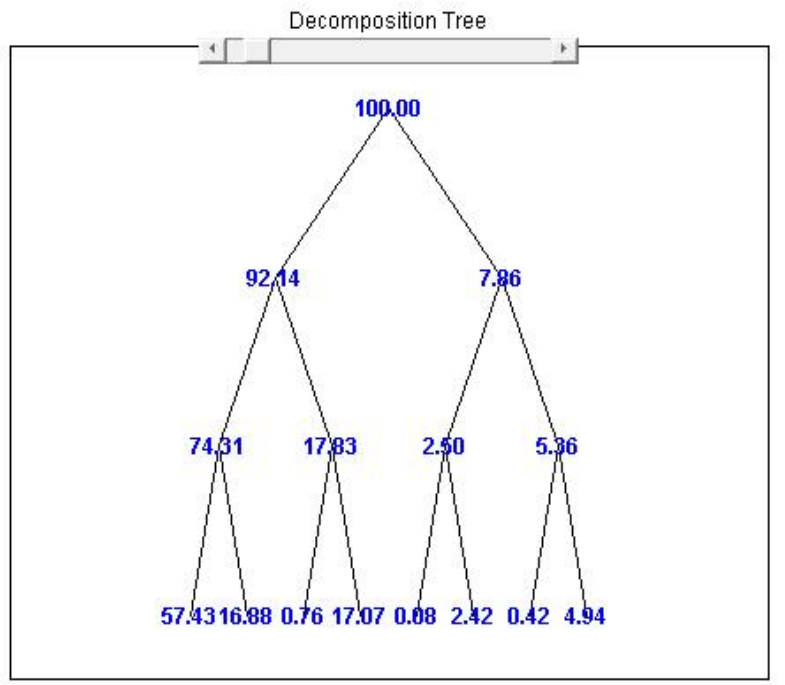

Fig.19 TRACK84_2_signal_2_2048_energie

Colored Coefficients for Terminal Nodes

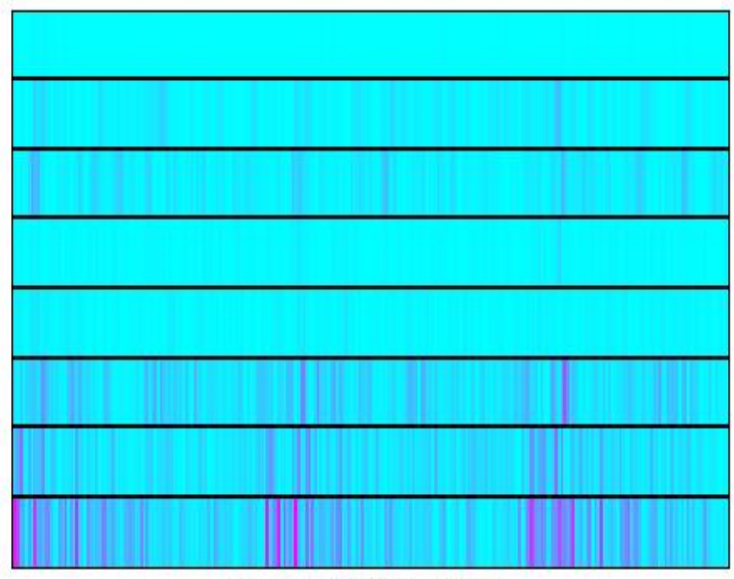

frequency ordered coefficients

Scale of Colors from Min to Max

Fig.20 TRACK84_2_signal_2_2048_energie

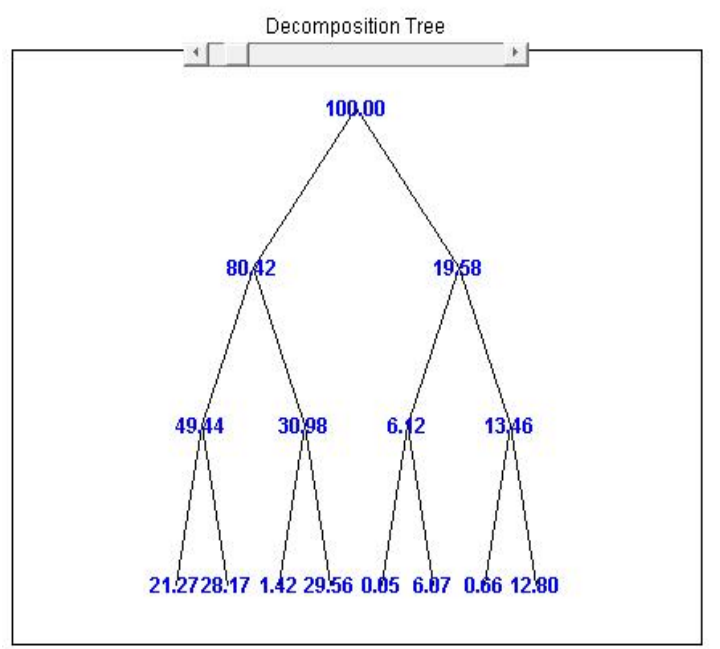

Fig.21 TRACK87_2_signal_2_2048_energie

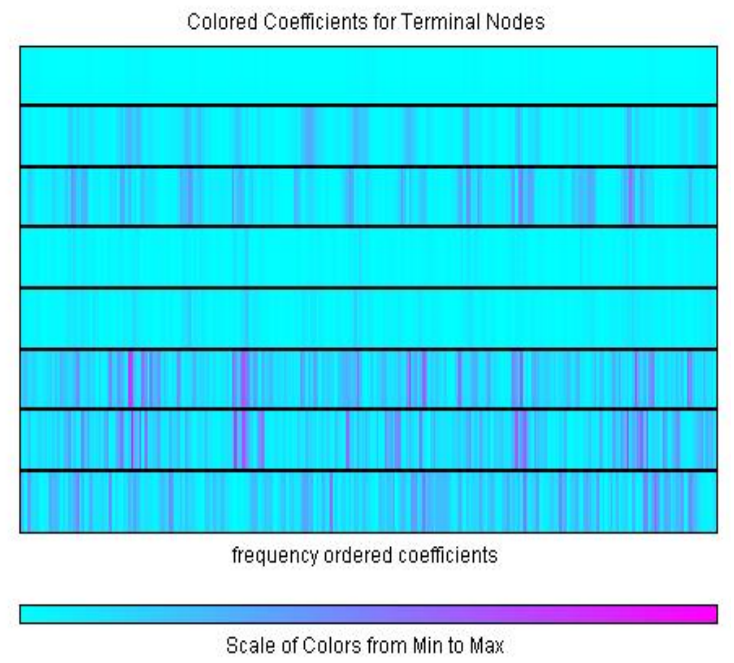

Fig.22 TRACK87_2_signal_2_2048_energie Decomposition Tree

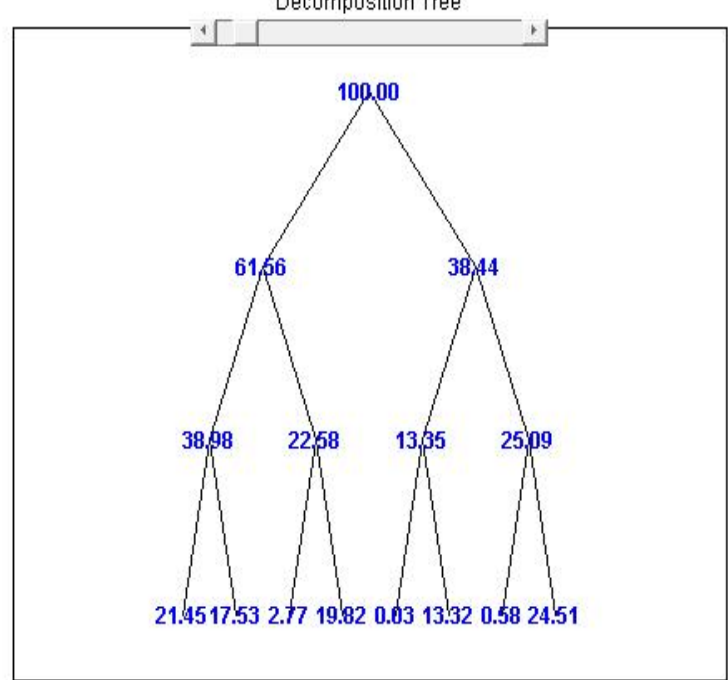

Fig.23 TRACK90_2_signal_2_2048_energie colored Coefficients for Terminal Nodes

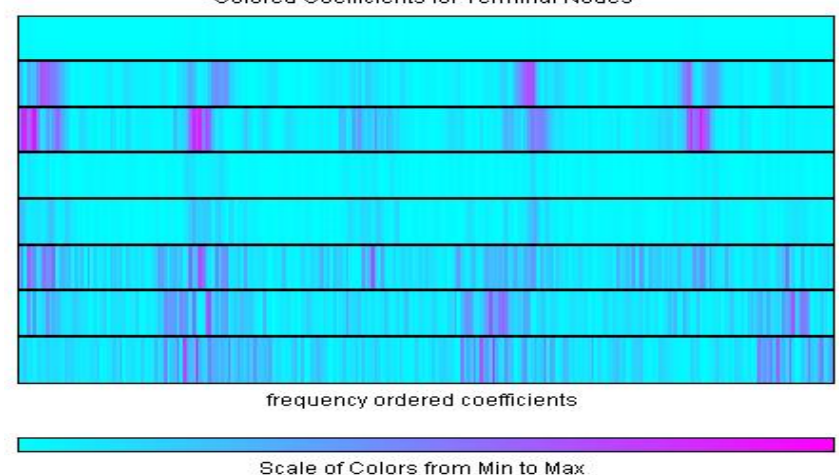

Fig.24 TRACK90_2_signal_2_2048_energie 
"Mircea cel Batran" Naval Academy Scientific Bulletin, Volume XIX - 2016 - Issue 1

Published by "Mircea cel Batran" Naval Academy Press, Constanta, Romania // The journal is indexed in: PROQUEST / DOAJ / DRJI / JOURNAL INDEX / I2OR / SCIENCE LIBRARY INDEX / Google Scholar / Crossref /

Academic Keys / ROAD Open Access / OAJI / Academic Resources / Scientific Indexing Services / SCIPIO

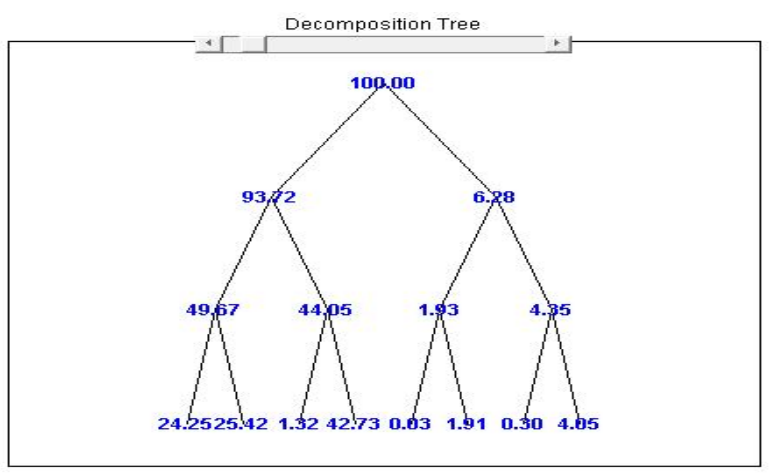

Fig.25 TRACK95_2_signal_2_2048_energie

Colored Coefficients for Terminal Nodes

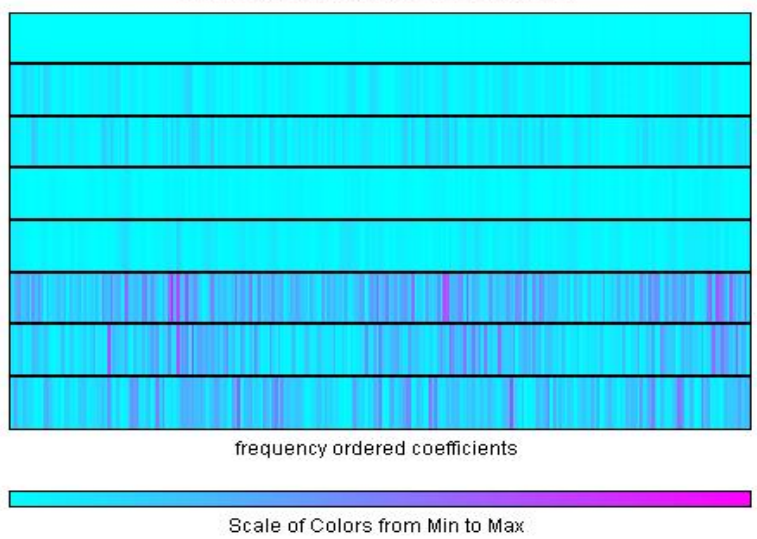

Fig.26 TRACK95_2_signal_2_2048_energie Tabel 4. Energy ratios in each frequency band

\begin{tabular}{|c|c|c|c|c|c|}
\hline 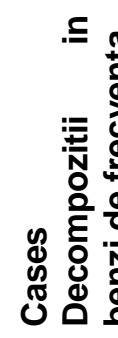 & 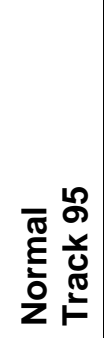 & 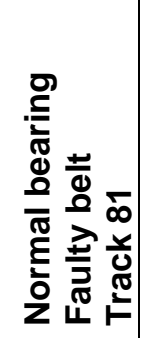 & 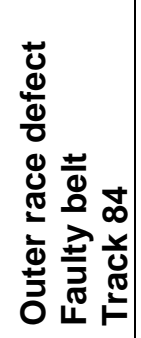 & 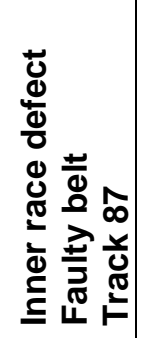 & 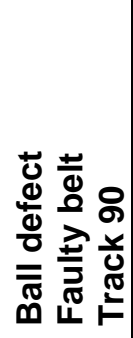 \\
\hline $\begin{array}{l}0- \\
200 \mathrm{H} \\
\mathrm{Z}\end{array}$ & $\begin{array}{l}24,2 \\
5\end{array}$ & 41,34 & 57,43 & 21,27 & 21,45 \\
\hline $\begin{array}{l}200- \\
400 \mathrm{H} \\
\mathrm{Z}\end{array}$ & $\begin{array}{l}25,4 \\
2\end{array}$ & 22,23 & 16,88 & 28,17 & 17,53 \\
\hline $\begin{array}{l}400- \\
600 \mathrm{H} \\
\mathrm{Z}\end{array}$ & 1,32 & 1,42 & 0,76 & 1,42 & 2,77 \\
\hline $\begin{array}{l}\text { 600- } \\
800 \mathrm{H} \\
\mathrm{Z}\end{array}$ & $\begin{array}{l}42,7 \\
4\end{array}$ & 25,56 & 17,07 & 29,56 & 19,82 \\
\hline $\begin{array}{l}800- \\
1000 \\
\mathrm{~Hz}\end{array}$ & 0,84 & 0,84 & 0,88 & 0,85 & 0,83 \\
\hline $\begin{array}{l}1000- \\
1200 \\
\mathrm{~Hz}\end{array}$ & 1,01 & 2,26 & 2,42 & 6,07 & 13,32 \\
\hline $\begin{array}{l}1200- \\
1400 \\
H z\end{array}$ & 0,30 & 0,99 & 0,42 & 0,66 & 0,58 \\
\hline $\begin{array}{l}1400- \\
1600 \\
\mathrm{~Hz}\end{array}$ & 4,85 & 6,16 & 4,94 & 12,80 & 24,51 \\
\hline
\end{tabular}

\section{CONCLUSIONS}

In this article we present three WT methods to demonstrate their applicability to extract defect in the drive belt and the location of his appearance and other defects in terms of different features in other elements of the gear. CWT used two wavelet functions, Morlet and Haar, in order to specify the effective detection and location of faults for different operating regimes in gear. The recorded signals were decomposed by WT, determining coefficients of wavelet through three methods DWT, CWT and WPT, report energy for each band by WPT, Local Maxima Lines for CWT and the identifying of the frequency band of interest for determining the fault of noise background. The experimental investigations were conducted on a stand diagnose faults using recording equipment Bruel \& Kjaer through three channels piezoelectric accelerometer connected to the Machine Diagnostics Toolbox 9727. Signal processing was done with Wavelet Toolbox of Matlab. By all three methods of investigation, we have determined those specific characteristics of the drive belt defects. It can appreciate that hybrid approach is effective for detection of faults with different features (periodic or impulse) found in rotating equipment.

\section{BIBLIOGRAPHY}

[1] G.G. Yen, K.-C. Lin, Wavelet packet feature extraction for vibration monitoring, IEEE Transactions on Industrial Electronics 47 (3) (2000) 650-667.

[2] Z.K. Peng, F.L. Chu, Application of wavelet transform in machine condition monitoring and fault diagnostics: a review with bibliography, Mechanical Systems and Signal Processing 18 (2004) 199-221.

[3] L. Li, L.S. Qu, X.H. Liao, Haar wavelet for machine fault diagnosis, Mechanical Systems and Signal Processing 21 (2007) 1773-1786.

[4] V. Purushotham, S. Narayanan, S.A.N. Prasad, Multi-fault diagnosis of rolling bearing elements using wavelet analysis and hidden Markov model based fault recognition, NDT \& E International 38 (2005) 654664. 
"Mircea cel Batran" Naval Academy Scientific Bulletin, Volume XIX - 2016 - Issue 1 Published by "Mircea cel Batran" Naval Academy Press, Constanta, Romania // The journal is indexed in: PROQUEST / DOAJ I DRJI / JOURNAL INDEX I I2OR / SCIENCE LIBRARY INDEX / Google Scholar / Crossref I Academic Keys I ROAD Open Access / OAJI / Academic Resources / Scientific Indexing Services / SCIPIO

[5] B. Isayed, L. Cheded, F. Al-Badour, Vibration monitoring and fault detection using wavelet techniques, ISSPA 2007 International Symposium on Signal Processing and its Applications, Dubai, UAE.

[6] MATLAB 6.5, Release 13, 2002, Wavelet Toolbox, The MathWorks, Inc. 